\title{
Alveolar Ridge Splitting for Implant Installation in Atrophic Sites. Analysis of a Case Series
}

\author{
División de Reborde Alveolar para Instalación de Implantes \\ en Sitios Atróficos. Análisis de una Serie de Casos
}

\author{
Sergio Olate, ${ }^{*+*}$; Álvaro Marín"; Gonzalo Oporto"; Daniel Farias ${ }^{*+*} \&$ Mario Cantín
}

OLATE, S.; MARÍN, M.; OPORTO, G.; FARIAS, D. \& CANTIN, M. Alveolar ridge splitting for implant installation in atrophic sites. Analysis of a case series. Int. J. Odontostomat., 9(2):249-254, 2015.

ABSTRACT: The alveolar ridge splitting technique (ARST) has been developed for close to 20 years, demonstrating effectiveness and efficiency in some cases. The aim of this study was to evaluate the behavior of the technique in a series of surgical cases using a piezoelectric system. Eleven patients (ASA I and ASA II) were included in this study. Subjects who smoked or who presented previous implant treatments or reconstructive surgeries in the treatment area were excluded. The surgeries took place under local anesthesia without sedation and consisted of a straight crestal incision and subsequent bone management with 4 different types of inserts mounted on a piezoelectric system, which were used gradually on the alveolar crest, moving down approximately $10 \mathrm{~mm}$. Once the approximately $3 \mathrm{~mm}$ expansion had been achieved, the implants were installed under controlled torque and the implant sites and defects present were filled with lyophilized bovine bone. In the splitting technique, there was a fracture of the bone plate in 4 cases, although in each case the implants were installed. A total of 34 implants were installed, of which 27 reached $35 \mathrm{~N}$ in installation and the rest between $20 \mathrm{~N}$ and $35 \mathrm{~N}$. In the second surgery 2 implants were lost. It can be concluded that the technique is predictable, of low morbidity and with rapid treatment completion, presenting limited intraoperative complications.

KEY WORDS: alveolar ridge splitting, bone atrophy, bone graft.

\section{INTRODUCTION}

Bone atrophy has been observed in different cases of dental loss. The presence of teeth ensures the stability of the maxillary and mandibular alveolar bone, so their loss also leads to bone loss in the medium and long term (Chen et al., 2004).

In cases of advanced bone loss, there is insufficient bone width for rehabilitation with osseointegrated implants, and other alternatives for bone increase must be considered. Traditionally, width defects are handled with partial bone reconstruction techniques with bone blocks, guided bone regeneration (GBR), horizontal osteogenic distraction and bone grafts (Anderson et al., 1993; Bedrossian et al., 2000; Cordaro et al., 2002); in some patients, the use of narrow implants can solve some cases, but when the bone width is $3 \mathrm{~mm}$ or less it is not feasible to contemplate the safe and stable installation of dental implants (Enislidis et al., 2006).

The alveolar ridge splitting technique (ARST) became popular in the 1990s through some promising research that demonstrated its efficiency (Simion et al., 1992; Scipioni et al., 1994); in these cases burs, saws, short discs and chisels were used. Despite its success, it became a complex technique and with a steep learning curve in some cases. Nowadays, with piezoelectric systems, it has once again become a stable technique, and although it requires special training, it can be performed without complications (Vercellotti et al., 2000).

* Division of Oral and Maxillofacial Surgery, Universidad de La Frontera, Temuco, Chile.

** Division of Oral Implantology, Universidad de La Frontera, Temuco, Chile.

*** Programa de Especialización en Implantología Oral, Universidad de Los Andes, Temuco, Chile.

*t*** PhD Program in Morphology, Universidad de La Frontera, Temuco, Chile.

****** Center for Biomedical Research, Universidad Autónoma de Chile, Temuco, Chile. 
Current results of implants installed with this technique have been encouraging, creating stability for rehabilitation, ultimate esthetic and short treatment time (Enislidis et al.). Nevertheless, the osteotomies conducted in these surgeries (mainly vertical sides) can complicate the technique.

The aim of this investigation was to study a series of cases using the ARST without lateral osteotomies and immediate implant installation.

\section{MATERIAL AND METHOD}

A case study series was designed to analyze the surgical/prosthetic treatment of patients undergoing the ARST. The study was developed in the Oral and Maxillofacial Surgery Unit and the Oral Implantology Unit at the Universidad de La Frontera (Temuco, Chile) in conjunction with the Facial Surgery Center (Private clinic, Temuco, Chile). From October 2012, 11 patients consented voluntarily to participate in the study and were admitted when they fulfilled the inclusion criteria, including total or partial dental absence of more than two adjacent teeth and good systemic health or controlled systemic disease (ASA I or ASA II). Patients who smoked, those with habitual alcohol intake and those who had undergone other previous reconstructive or implant procedures in the same area were excluded.

For this study a descriptive analysis of the installed implants was designed, considering intraoperative complications both in the expansion and installation of the implants, stability of the implant and bone loss. The prosthetic response will be evaluated in the next study.

All the procedures were performed under local anesthesia and without sedation. Atrophic mandibular and maxillary sectors were used for the development of the treatment sequence. All the patients were prepared initially with study models that permitted surgical and prosthetic planning as well as the non-strict surgical guide for intraoperative use.
After application of conventional local anesthesia techniques, a full thickness incision was made at crestal level on keratinized tissue. The incision extended to the next tooth or at least $5 \mathrm{~mm}$ more anterior or posterior from the end of the osteotomy indicated, securing direct observation of the alveolar crest. An approximately $6 \mathrm{~mm}$ deperiostization was performed in the vestibular area to obtain visibility of the operating site and subsequent recognition of any alteration in the implant installation.

With a direct view of the alveolar crest, if the ridge presented a width close to $1.5 \mathrm{~mm}$, the ARST was performed immediately; if it presented less than $1.5 \mathrm{~mm}$, then it was worn down with a diamond bur (low speed motor at $1800 \mathrm{rpm}$ ) to reduce the height, obtaining an improved alveolar crest width up to approximately $1.5 \mathrm{~mm}$. With this condition the bone splitting technique could be performed using the piezoelectric system (Piezotome $2 \AA$, Satelec Action, France), calibrating the device on the D1 setting and using profuse saline irrigation. The preparation sequence was begun with the CS3 insert until a total depth of $10 \mathrm{~mm}$ was achieved across the entire extension of the ridge. The procedure continued with the CS1 insert and finally the CS2 insert. The CS\% insert was used in two patients with the possibility of widening the osteotomy segment; this sequence always achieved a complete extension in depth of application (Fig. 1).

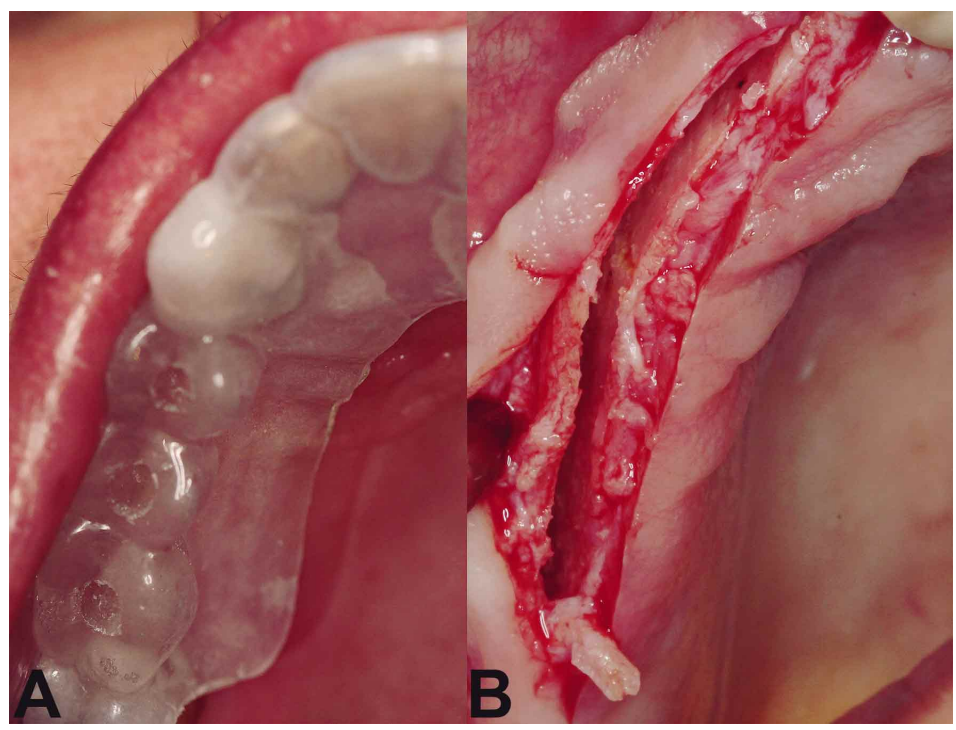

Fig. 1. A) Surgical guide in position. B) Alveolar ridge splitting technique in the second stage.

The conclusion of the expansion sequence was followed by preparation for implant installation, which began with a lance drill to planned depth, followed by the drill sequence with normal instrumentation in most cases; in some cases sub instrumentation was needed. Conical implants were used with internal connections (Conect $A R \AA$, Conexao Sistema de Prótese, Brazil; Tapered $囚$, Zimmer, USA) and due to the design 
needed for the low-stress installation in the expanded segment and the need for apical fixation, using 3.5 to $4 \mathrm{~mm}$ wide and 10 to $13 \mathrm{~mm}$ high implants (Fig. 2). The implants were installed with motor and programmed torque control at $35 \mathrm{~N}$, according to the manufacturer's instructions for the installation model. Once stabilized, the implants were maintained with their sealing cap. The bone defects present and the
Post-operative checks took place at weeks 1, 2 and 4 . When necessary, a removable prosthesis was used 3 days after the procedure. After 5 months, the implants were evaluated by $\mathrm{x}$-ray and a second surgery was performed to install their healing abutment; after two weeks the prosthetic rehabilitation phase began (Fig. 4) following regular development parameters as per to the previous planning.

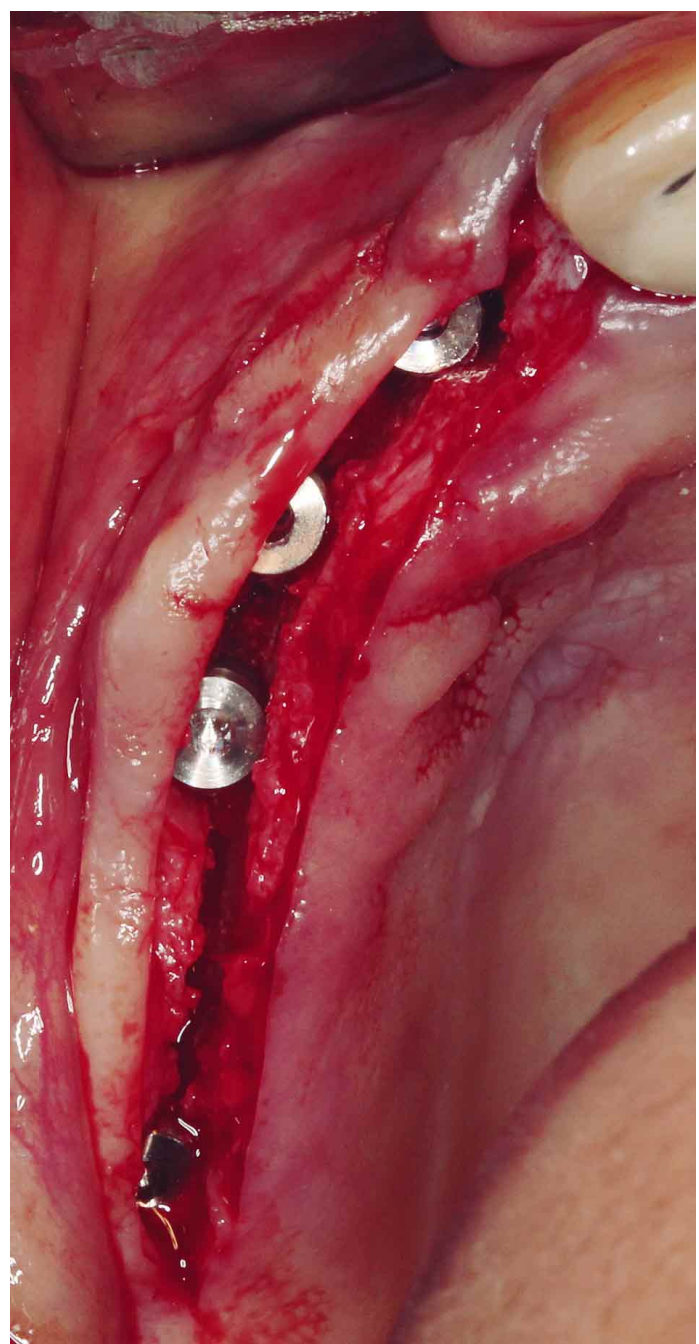

Fig. 2. Four dental implants in position, over $20 \mathrm{~N}$ in torque.

remaining spaces caused by the expansion were filled up with lyophilized bovine bone (Bio-Oss $®$, Geistlich Pharma) achieving obturation in all the sites (Fig. 3).

After surgical verification and cleaning of the area, the suture technique was performed with $4 / 0$ or $3 / 0$ chromic catgut or $4 / 0$ vicryl with continuous and single suturing to ensure flap tension and primary closure of the surgical wound.

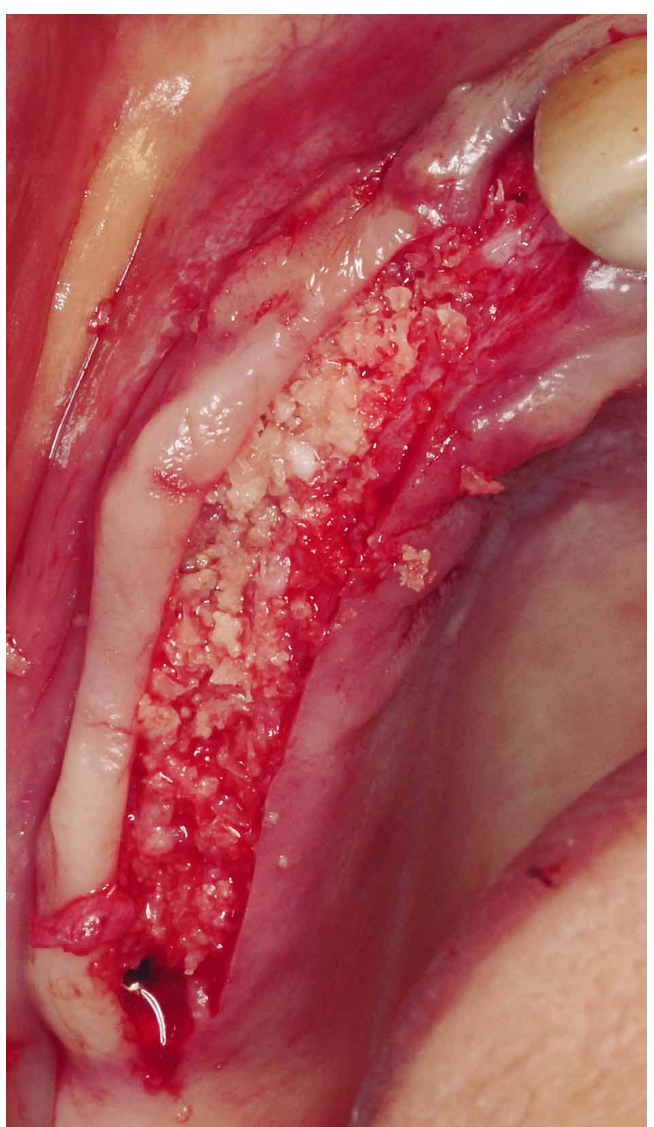

Fig. 3. Bone graft in position over the death space and implant.

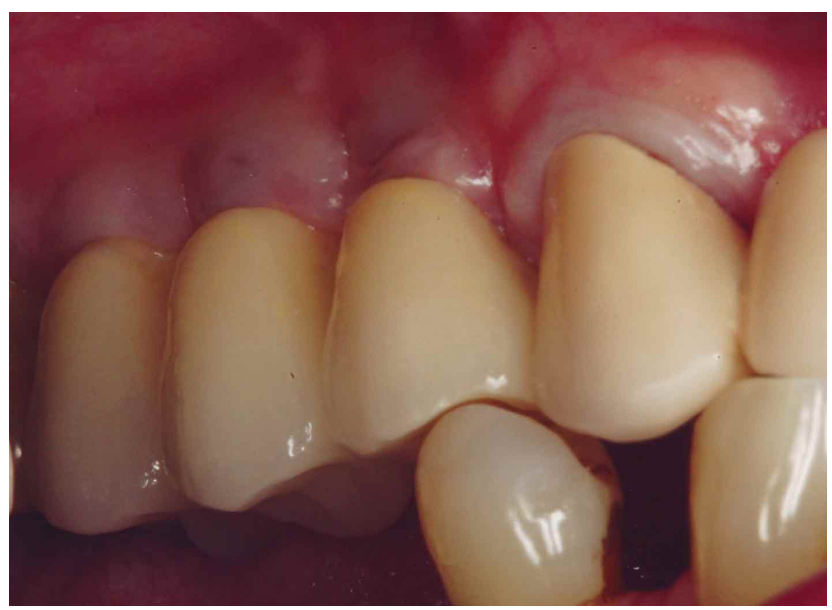

Fig. 4. Final restoration with full crown with the implant position. 


\section{RESULTS}

Eleven patients with an average age of 52 years (43-67), 4 male and 7 female, underwent surgery. No systemic complications were observed, nor any other type of alteration to the original protocol offered.

During the ridge splitting phase, a partial fracture of the vestibular or lingual table was observed in 4 cases (Fig. 5). This fracture was generated mainly by the lack of bone support and occurred in the mid sector of the split, allowing the installation of the implants in the distal sectors of the fracture. These implants were installed without complications and the fracture site was filled with lyophilized bovine bone, and in two cases rapidly absorbing biological membrane was used to improve the adaptation of the bone graft. In another three cases there was a fault in the angulation of the insert, which required lingual desperiostization to define the best insertion pathway for the insert; the correction was made without complications. In two cases there were limitations in the suturing phase due

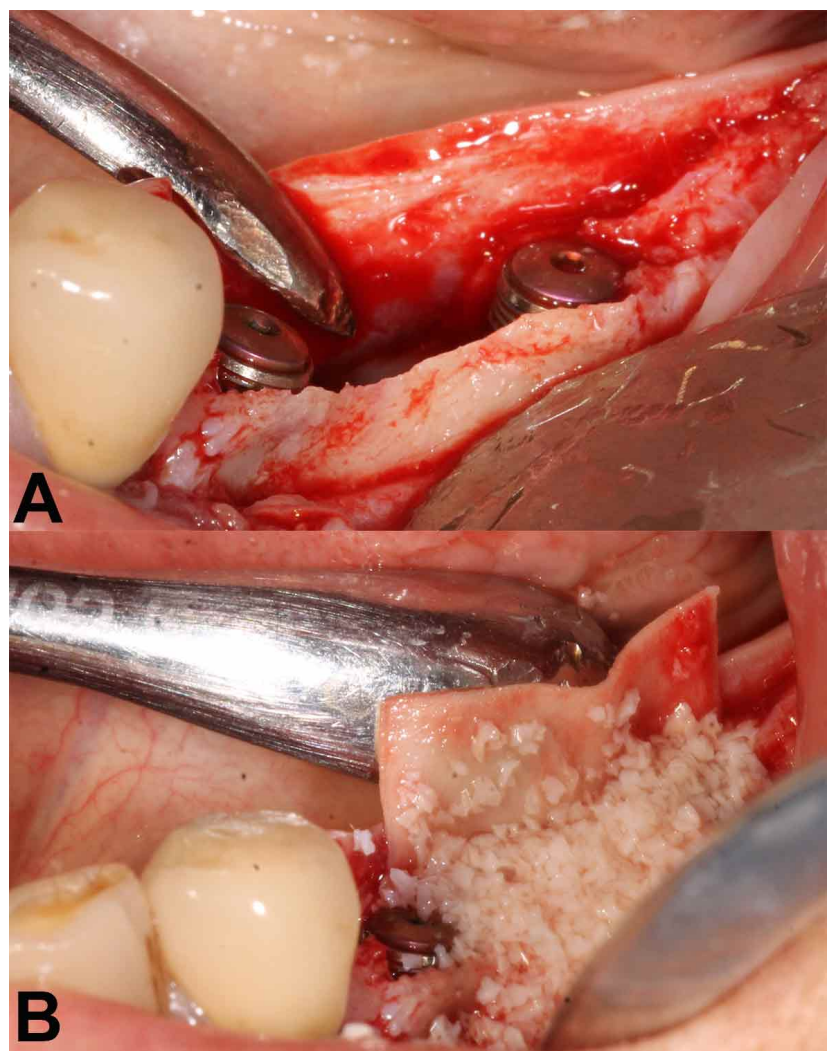

Fig. 5. A) Extensive fracture of the lingual plate. The implants were installed with $35 \mathrm{~N}$ and $20 \mathrm{~N}$, supported by the remaining bone plate. B) Bone filling of the entire sector with lyophilized bovine bone and coverage with reabsorbible biological membrane to model the present defect. to the lack of soft tissue to achieve total obturation of the wound; in these cases a repair was made on the second attempt to close the wound.

Thirty-four implants were installed with the proposed technique. In 27 stability was achieved with $35 \mathrm{~N}$ of torque and in 7 less stability was obtained, all were greater than $20 \mathrm{~N}$. All the implants were inserted up to cervical level, as indicated by the manufacturer or lower according to the presence of adjacent bone plates (Fig. 6). In the second surgery the loss of two implants was observed $(5.88 \%)$ in relation to the prosthetic load. The bone remodeling observed was adequate and in agreed with normal sites.

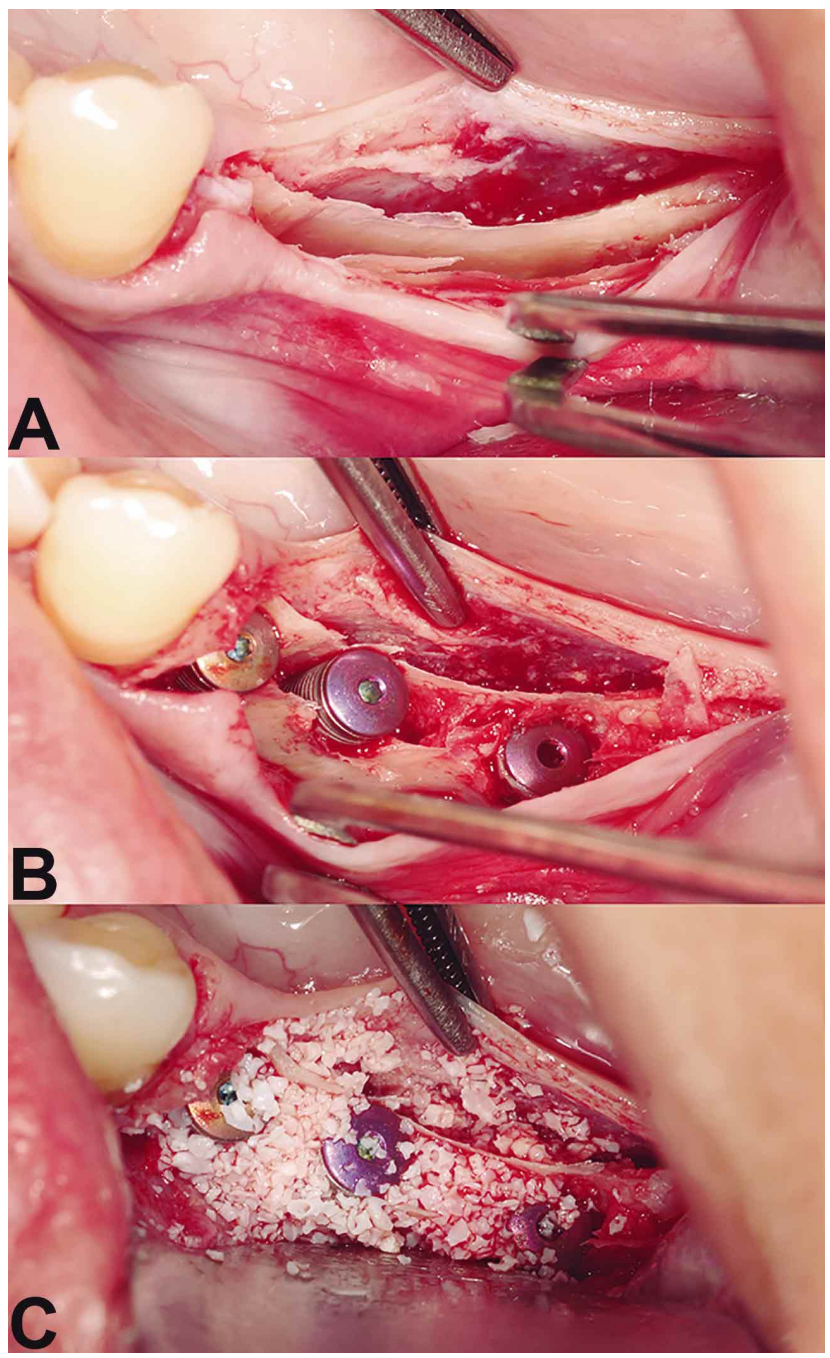

Fig. 6. A) Clinical condition in mandibular sector after application of the third insert with full depth of $10 \mathrm{~mm}$. B) 3 implants installed in the posterior mandibular sector, all with over $35 \mathrm{~N}$ of torque; the spaces and defects generated by the process are observed. C) Bone filling with lyophilized bovine bone covering all the defects present between the implants and in the lateral sectors. 


\section{DISCUSSION}

The alveolar ridge splitting technique (ARST) was proposed in the 1990s by Simion et al. to install implants in sites with broad bone atrophy, sufficient height, less treatment time and less morbidity. Our results have shown good success and low morbidity with the technique, performing the osteotomy exclusively at alveolar crest level, enabled mainly by the piezoelectric system insert scale.

Sohn et al. (2010) reported a study of 32 patients using the ARST; they used an osteotomy in the alveolar crest and then a vertical osteotomy to enable displacement of the vestibular bone plate, initially proceeding with an ultrasonic system and later separating with a smaller chisel. In the ARST sequence with immediate implant, 5 out of 21 cases presented a bone plate fracture. Sohn et al. reported that an alveolar ridge of at least 3 to $4 \mathrm{~mm}$ would be necessary because with less width the division would be made almost exclusively on cortical bone, which would increase the likelihood of fracture. Our results confirm the possibility of cortical bone fracture, although this occurs mainly at cervical level; implant stability is in the apical region with the result of osseointegration at that level.

To avoid a bone plate fracture, Piccinini (2009) proposed the ARST with the removal of the external plate in order to insert it again later and fix it with osteosynthesis screws. The goal of implant installation is reached, but through a more morbid surgery, losing one of the initial objectives of the single osteotomy ARST of reduced morbidity. In addition, the incorporation as a graft establishes low irrigation and risk of bone necrosis. A similar system was proposed by Basa et al. (2004), who presented 30 patients who underwent the ARST with subsequent removal and reinstallation of the lateral bone plate: no implant loss was reported, indicating stability of the technique.

Scipioni et al. (1994) showed that the persistence of 1 to $1.5 \mathrm{~mm}$ of lingual and buccal bone plate can ensure the stability of the implants and total osseointegration, considering then at least $3 \mathrm{~mm}$ in width to perform this maneuver. In the opinion of these authors, implant stability is mainly guaranteed by the apical region, so that the implant conditions used are important for correct apical anchorage. Implants with aggressive and extended screws could make the insertion of implants difficult with these types of techniques (Olate et al., 2011). The conical characteristics of the acute apical zone are useful for reducing the fracture risk. Perhaps the main disadvantage of this technique is that it does not resist significant variations in the position of the implant, which will follow the direction of the bilateral alveolar ridge.

The use of the piezoelectric system gives a fundamental qualitative advance to this technique. It allows control and safety in the osteotomy as well as adequate visibility in the intraoperative stage (Olate et al., 2013). Our experience is exclusively with the piezoelectric system insert scale, without the use of a chisel and with low intraoperative noise, which improves the patient's acceptance of the technique. Previous experiences with other cutting systems reveal that it can be done but there is cutting irregularity and the cuts are bigger (Pozzer et al., 2013).

Another relevant aspect of the ARST is that in some cases bone graft is used, as indicated by other researchers (Sohn et al.); nevertheless, Scipioni et al. $(1994,1997)$ reported that this graft may not be necessary given that the implants are going to maintain osseointegration in their primary contact with bone and have difficulty doing so with grafted bone. Shimoyama et al. (2001), however, recommended the installation of biological membranes to secure the grafted area; the authors agree with this indication and in the fact that the osseointegration would not be achieved in the biomaterial graft installed; however, the esthetic reasons for better contour and adjustment for the emergence of rehabilitation may lead to the use of these materials. The defect generated between the implants is small and can act as a non-critical defect (Chaves Netto et al., 2009) with adequate regeneration; in addition, the periosteum collaborates substantially in bone regeneration (Guirardo et al., 2005) which would be limited with the use of some types of membrane.

Finally, we can conclude that the ARST together with adequately designed implants are useful for solving cases with bone that is atrophic in width, decreasing the number of indications from previous reconstructive techniques.

\section{ACKNOWLEDGEMENTS}

To Conexäo Sistema de Prótese, Centro Industrial - Arujá - São Paulo - Brazil, for its collaboration to provide products and develop this research under the Protocol 01.09/13. To Universidad de La Frontera Project DIE15-006. 
OLATE, S.; MARÍN, M.; OPORTO, G.; FARIAS, D. \& CANTIN, M. División de reborde alveolar para instalación de implantes en sitios atróficos. Análisis de una serie de casos. Int. J. Odontostomat., 9(2):249-254, 2015.

RESUMEN: La técnica de división de reborde alveolar (DRA) tiene cerca de 20 años de evolución demostrando efectividad y eficiencia en algunos casos. El objetivo de este estudio es evaluar el comportamiento de la técnica en una serie de casos operados con sistema piezoeléctrico. Once pacientes (ASA I y ASA II) fueron incluidos en este estudio; se excluyeron sujetos fumadores o que presentaran tratamientos implantológicos o quirúrgicos reconstructivos previos en el área a tratar; las intervenciones se desarrollaron bajo anestesia local, sin sedación y consistió en una incisión crestal recta y posteriormente el manejo óseo con 4 tipos diferentes de insertos montados en sistema piezoeléctrico los que fueron utilizados gradualmente sobre la cresta alveolar profundizando hasta los $10 \mathrm{~mm}$ aproximadamente; una vez obtenida la expansión de $3 \mathrm{~mm}$ aproximadamente se procedió a la instalación de implantes bajo torque controlado y relleno con hueso liofilizado bovino de los sitios implantados y defectos presentes. En la técnica de división, en 4 casos existió fractura de la tabla ósea, aunque en todos ellos fueron instalados los implantes. Se instalaron un total de 34 implantes de los cuales 27 consiguieron los $35 \mathrm{~N}$ en instalación y el resto presento de entre $20 \mathrm{~N}$ y $35 \mathrm{~N}$; en la segunda cirugía se observo una perdida de 2 implantes. Se puede concluir que la técnica es predecible, de baja morbilidad y de rápida finalización de tratamiento, presentando limitadas complicaciones intraoperatorias.

PALABRAS CLAVE: división de reborde alveolar, atrofia ósea, injerto óseo.

\section{REFERENCES}

Andersson, B.; Odman, P.; Widmark, G. \& Waas, A. Anterior tooth replacement with implants in patients with a narrow alveolar ridge form. A clinical study using guided tissue regeneration. Clin. Oral Implants Res., 4(2):90-8, 1993.

Basa, S.; Varol, A. \& Turker, N. Alternative bone expansion technique for immediate placement of implants in the edentulous posterior mandibular ridge: a clinical report. Int. J. Oral Maxillofac. Implants, 19(4):554-8, 2004.

Bedrossian, E.; Tawfilis, A. \& Alijanian, A. Veneer grafting: a technique for augmentation of the resorbed alveolus prior to implant placement. A clinical report. Int. J. Oral Maxillofac. Implants, 15(6):853-8, 2000.

Chaves Netto, H. D. M.; Olate, S.; Chaves, M. G. A. M.; Barbosa, J. R. A. \& Mazzonetto, R. Histological analyses of osseous repair defects. recognized of critic defects. Int. J. Morphol., 27(4):11217, 2009.

Chen, S. T.; Wilson, T. G. Jr. \& Hämmerle, C. H. Immediate or early placement of implants following tooth extraction: review of biologic basis, clinical procedures, and outcomes. Int. J. Oral Maxillofac. Implants, 19 Suppl.:12-25, 2004

Cordaro, L.; Amadé, D. S. \& Cordaro, M. Clinical results of alveolar ridge augmentation with mandibular block bone grafts in partially edentulous patients prior to implant placement. Clin. Oral Implants Res., 13(1):103-11, 2002.

Enislidis, G.; Wittwer, G. \& Ewers, R. Preliminary report on a staged ridge splitting technique for implant placement in the mandible: a technical note. Int. J. Oral Maxillofac. Implants, 21(3):445-9, 2006.

Guirado, J. L.; Yuguero, M. R.; Carrión del Valle, M. J. \& Zamora, G. P. A maxillary ridge-splitting technique followed by immediate placement of implants: a case report. Implant Dent., 14(1):1420, 2005.

Olate, S.; Chaves Netto, H. D.; Klüppel, L. E.; Mazzonetto, R. \& Albergaria-Barbosa, J. R. Mineralized tissue formation associated with 2 different dental implant designs: histomorphometric analyses performed in dogs. J. Oral Implantol., 37(3):319-24, 2011.
Olate, M. S.; Almeida, A. A.; Unibazo, Z. A.; Alister, H. J. P.; Uribe, F. F.; Martinez, V. F. \& Huentequeo-Molina, C. Osteotomías craneomaxilofaciales con sistemas ultrasónicos. Rev. Chil. Cir., 65(5):454-62, 2013.

Piccinini, M. Mandibular bone expansion technique in conjunction with root form implants: a case report. J. Oral Maxillofac. Surg., 67(9):1931-6, 2009.

Pozzer, L.; Cavalieri-Pereira, L.; Olate, S.; Albergaria-Barbosa, J.; Asprino, L. De Moraes, M. Splint crest technique for alveolar bone in posterior region of mandible with immediate implant. Int. J. Odontostomat., 7(1):29-32, 2013.

Scipioni, A.; Bruschi, G. B. \& Calesini, G. The edentulous ridge expansion technique: a five-year study. Int. J. Periodontics Restorative Dent., 14(5):451-9, 1994.

Scipioni, A.; Bruschi, G. B.; Giargia, M. Berglundh, T. \& Lindhe, J. Healing at implants with and without primary bone contact. An experimental study in dogs. Clin. Oral Implants Res., 8(1):39-47, 1997.

Shimoyama, T.; Kaneko, T.; Shimizu, S.; Kasai, D.; Tojo, T. \& Horie, N. Ridge widening and immediate implant placement: a case report. Implant Dent., 10(2):108-12, 2001.

Simion, M.; Baldoni, M. \& Zaffe, D. Jawbone enlargement using immediate implant placement associated with a split-crest technique and guided tissue regeneration. Int. J. Periodontics Restorative Dent., 12(6):462-73, 1992.

Sohn, D. S.; Lee, H. J.; Heo, J. U.; Moon, J. W.; Park, I. S. \& Romanos, G. E. Immediate and delayed lateral ridge expansion technique in the atrophic posterior mandibular ridge. J. Oral Maxillofac. Surg., 68(9):2283-90, 2010.

Vercellotti, T. Piezoelectric surgery in implantology: a case report--a new piezoelectric ridge expansion technique. Int. J. Periodontics Restorative Dent., 20(4):358-65, 2000.

Correspondence to:

Prof. Sergio Olate, $\mathrm{PhD}$

División de Cirugía Oral y Maxilofacial

Universidad de La Frontera

Temuco- CHILE

Email: sergio.olate@ufrontera.cl

Received: 04-03-2014

Accepted: 17-05-2015 